\title{
The Role of the Management Accounting System and Decision-Making Style on Managerial performance
}

\author{
David Efendi ${ }^{1}$, Emeralda Ayu Kusuma ${ }^{2}$ \\ 1,2 Sekolah Tinggi Ilmu Ekonomi Indonesia Surabaya, Indonesia \\ *Corresponding Author: david@stiesia.ac.id
}

\begin{abstract}
This study aimed to provide empirical evidence on the relationship between the management accounting system (MAS) and decision-making style on cooperatives' managerial performance in Ponorogo. Data were collected from 119 questionnaires, while 60 questionnaires could be analyzed. Then, SPSS was applied to test non-response bias and descriptive statistics. SmartPLS was used for hypothesis testing. Research findings indicated that MAS did not affect managerial performance, and the decision-making style affected managerial performance.

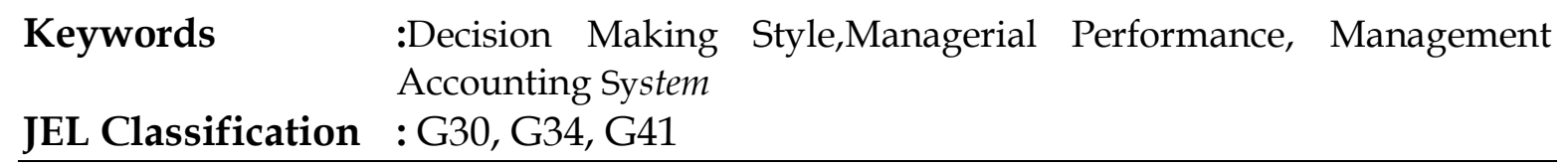

\section{INTRODUCTION}

Managerial performance is essential in all organizations (Mihaela-Lavinia \& Luciana, 2011). It has been an exciting topic since Fayol published his study in 2016. Managerial performance is impressive due to some reasons. First, managerial performance is an indicator of a manager's success in achieving goals (Zenita, Sari, Anugerah, \& Said, 2015). It also reflects economic performance and profitability (Arcelus, Melgarejo, \& Simón, 2014). Managerial performance designates individuals' level of success (Mahoney, Jerdee, \& Carroll, 1965). Moreover, good managerial performance will achieve business success (Dafna, 2008) through a decision-making process that utilizes information (Zenita et al., 2015). Indeed, decision making is part of the management task (Cosgrave, 1996). Baba and HakemZadeh (2012) argue that decision making is the essence of management duties; so it is necessary to make the right decisions. Decision-making is more contented and effective by utilizing knowledge as a part of the accounting system (Zimmerman, 2009) and information (Zenita et al., 2015) by providing accounting information within the organization (Siyanbola, 2012).

The management accounting system (MAS) is an accounting information system that provides managers information (Alikhani, Ahmadi, \& Mehrava, 2013). MAS is essential in the decision-making process (S.O. Ajibolade, Arowomole, \& Ojikutu, 2010) since MAS produces information (Solabomi O. Ajibolade, 2013). MAS in the organization assists 
decision-makers in carrying out management tasks (Indriani \& Nadirsyah, 2015). Instead, MAS has a relationship with managerial performance (Tsui, 2001) to improves managerial quality (Vincent K Chong \& Eggleton, 2003) and as a source of organizational competitive advantage (Atkinson, Kaplan, Matsumura, \& Young, 2010). However, MAS has been debated by practitioners and academics (Zoni, Dossi, \& Morelli, 2012) that lead to MAS research among accounting academics (Seaman \& Williams, 2006).

MAS is vital for organizations for some reasons. First, the system responds to manager requests for information needs (Lääts \& Haldma, 2012). MAS also converts a reference in changing the external environment (Waweru, 2008). Third, the interaction between MAS and budgetary participation affects managerial performance (Tsui, 2001). Fourth, all the characteristics possessed by MAS are positively related to managerial performance (Sohrabi, Talebnia, \& Nikjoo, 2014; Soobaroyen \& Poorundersing, 2008). Fifth, MAS provides planning and control information needs (Sohrabi et al., 2014). Sixth, the system safeguards organizational rules, procedures, and employees (Sisaye \& Birnberg, 2014). Seventh, MAS has principles following stakeholder theory and relates to manager behavior in rational decision making (Rausch, 2011). Last, MAS supports managerial decision making and controls (Abernethy \& Bouwens, 2005).

MAS's prominence makes it the object of research worldwide. Studies investigating the relationship between MAS and managerial performance were conducted by Gul (1991), Gul and Chia (1994), Chia (1995), Vincent K Chong (1996), Vincent K. Chong (1998), Vincent K Chong and Eggleton (2003), Soobaroyen and Poorundersing (2008), Agbejule (2005), Hammad, Jusoh, and Oon (2010), Hammad, Jusoh, and Ghozali (2013), Chung, Su, and Yu-Ju (2012), Sohrabi et al. (2014), and others. Although MAS research has not been a new issue, there is a contradiction to the previous studies. Therefore, the researcher intended to test and re-analyze the relationship between MAS and managerial performance in the cooperatives with the mediation of decision-making style (DMS) to analyze the relationship between MAS and managerial performance.

Furthermore, cooperatives rapidly change the economic environment structure due to globalization and agricultural industrialization (Royer, 1999). They are an economic alternative and feasible in the form of powerlessness (Bello \& Zaria, 2005). Cooperatives are generated as institutions that fully defend themselves by seeking profit, as theoretically cooperatives are business organizations (Robotka, 1947). In Indonesia, cooperatives were known in colonial times as economic institutions with limited roles in assisting their members (Subandi, 2008).

This study applied a decision-making style (DMS). The style is an individual characteristic in perceiving and responding to decision-making behavior (Spicer \& SadlerSmith, 2005). The variable is crucial for managerial performance (Ali, 1993) and affects individuals' decision-making tasks (Scott \& Bruce, 1995). The style also contributes to understanding the decision-making process (Reyna, Ortiz, \& Revilla, 2014) and reflects individual characteristics in observing and responding to the decision-making process (Harren, 1979).

Based on the previous descriptions, this study investigated how the management accounting system (MAS) increased managerial performance and how a decision-making style improved managerial performance. The research problems can then be formulated: (1) Does the management accounting system (MAS) positively affect managerial performance? And (2) Does the decision-making style affect managerial performance? 
Moreover, this study aimed to analyze and determine the effect of the management accounting system (MAS) on managerial performance empirically and the effect of decision-making styles on managerial performance empirically.

\section{HYPOTHESES DEVELOPMENT}

\section{Effect of Management Accounting System on Managerial Performance}

Information is an essential element in human activities. Individuals and organizations have developed information need with advanced technology (Alikhani et al., 2013). Accounting is one of the information systems information that integrates and connects the environment and technical elements of human potential into a follow-up unit (Tokic, Spanja, Tokic, \& Blazevic, 2011). An organization's accounting information system involves two systems: financial accounting system and management accounting system (Alikhani et al., 2013).

The management accounting system (MAS) provides internal information to management decision-making (Watts, Yapa, \& Dellaportas, 2014). The management relies on MAS in a tactical position instead of its change determination. MAS guarantees utility as a service tool for managers as the formal information subsystem within organizations (Moliner \& Ruiz, 2004). It develops a combination of multidimensional planning and control subsystems (Williams \& Seaman, 2002) and delivers managers with the required information to make decisions (Jerman, Kavčič, \& Korošec, 2012). A company's system aims to provide timely and relevant information to facilitate decision-making and motivate employees to achieve organizational goals (Zimmerman, 2001).

Managerial performance has been an exciting research topic since Fayol published his work in 1916 (Borman \& Brush, 1993). The managerial performance can influence organizational culture and productivity (Young, Winfred Arthur, \& Finch, 2000) and the behavioral consequences (Staw \& Barsade, 1993). The performance has important domains: knowledge, leadership, communication, and interpersonal behavior (Young et al., 2000). The domains are identified as part of managerial work: leadership, communication, and interpersonal behavior (Borman \& Brush, 1993).

Previous studies contributed to improving understanding of managerial performance's nature. Two dimensions relevant to managerial performance are managerial functions and managerial competence (Mahoney et al., 1965). They provide a framework for analyzing a manager's work. Many researchers use even the instrument of managerial functions dimensions. Meanwhile, managerial competence focuses on technical competence or knowledge areas, which include employees, finance, material and goods, purchases and sales, methods and procedures, facilities, and equipment.

Managerial performance is an indicator of a manager's success in realizing goals that must be improved from time to time through improved decision-making processes (Zenita et al., 2015). Furthermore, Zenita et al. (2015) added that managers use information in the decision-making process and make effective decisions. One significant source of information is the Management Accounting System (MAS), which can be conceptualized as an essential part of an organization's formal planning process and assists managers in the decision-making process (Rinsum, 2006). Besides, MAS has a primary goal: achieving organizational goals (Rasid, Isa, \& Ismail, 2014) through providing information and techniques to managers and employees to control, coordinate and facilitate decision making (Rausch, 2011). In other words, MAS is a type of system that helps managers 
access and use management accounting information to achieve goals and improve managerial performance (Chung et al., 2012). All will improve the existing performance in the organization (Robert H. Chenhall, 2003; Ismail \& Isa, 2011).

MAS is required to achieve the desired performance (Ismail \& Isa, 2011). It is a formal system designed to provide managers information (Bouwens \& Abernethy, 2000) and influences the manager's decision making (Rausch, 2011). Besides, MAS is also related to managerial performance (Tsui, 2001) and even improves managerial performance (Chung et al., 2012). In brief, MAS aims to provide management information for business planning and control (Wessels \& Vermaas, 1998).

Chia (1995) found that MAS contributes to managerial performance. Chang, Chang, and Paper (2003) also found that performance can be improved with MAS availability. Other findings showed that all characteristics are positively related to managerial performance (Robert H Chenhall \& Morris, 1986; Soobaroyen \& Poorundersing, 2008). The MAS-broad scope also affects managerial performance (Chia, 1995; Mia \& Chenhall, 1994). These are corroborated by Sohrabi et al. (2014) that MAS-broad scope is positively related to non-financial managers' performance. Soobaroyen and Poorundersing (2008) also argue that all MAS dimensions are positively related to managerial performance. The information will have an impact on performance. MAS is one of the information in an organization that can improve managerial performance. Consequently, the hypothesis is developed below:

H1. Management Accounting System positively affected managerial performance.

\section{Decision-Making Style and Managerial Performance}

Various understandings have been discussed about the style of decision making. Taylor discussed the decision-making style in a book entitled "The Principles of Scientific Management" in 1947 (Rowe \& Boulgarides, 1983). Scott and Bruce (1995) define it as learning response patterns when individuals face with decision-making situations. The decision-making style symbolizes "the habit-based response to learning habits to react in a certain way to a decision" (Verma \& rangnekar, 2015). Two fundamental questions may distinguish decision-making style: how information is used and how to make choices; these are derived into four styles: decisive, flexible, hierarchic, and integrative (Brouseeau, Driver, Hourihan, \& Larsson, 2006). In contrast, Conteh (2005) divides decision-making styles into Analytic Autocratic, Heuristic Autocraticm Analytic Consultative, and Heuristic Consultative.

Scott and Bruce (1995) developed a decision-making style from the model proposed by Harren (1979), i.e., rational, intuitive, and dependent. They also add from Phillips, Pazienza, and Ferrin (1984) findings with the emergence of a decision style, namely avoidant style. Scott and Bruce (1995) divide decision-making style into five: (1) rational style, (2) intuitive style, (3) dependent style, (4) avoidant style, and (5) spontaneous style. The development is the most widely used instrument for measuring decision-making styles (Curseu \& Schruijer, 2012).

Amazt and Idris (2011) state that the literature shows a positive correlation between participation in decision making and staff productivity. Individual decision making will have an impact on productivity. Others find that the decision-making style affects lecturers' job satisfaction at the University (Amazt and Idris, 2011). While Moghadam, 
Tehrani, and Amin (2011) argue that emotional intelligence is negatively related to rational style, and dependent style and spontaneous is not related to emotional intelligence.

Kao, Kao, Chen, and Chiu (2012) initiate that rational style has a positive relationship with management knowledge, and avoidant style has a negative relationship with executive management knowledge. The rational style is the dominant style of decision making. Verma, Bhat, Rangnekar, and Barua (2015) support the findings that the central decision-making styles are rational and avoidant. Baiocco, Laghi, and D'Alessio (2009) demonstrate that rational style has a positive relationship with school achievement. Thus the decision-making style taken by individuals will result in the achievement of goals. So, the hypothesis is developed below:

H2. Decision-making style affected managerial performance

\section{METHOD, DATA, AND ANALYSIS}

\section{Types and Sources of Data}

This study applied primary data for analysis. The data were obtained by distributing questionnaires to cooperative managers in Ponorogo Regency. Cooperatives were considered the objects of this study due to Hammad et al. (2013), who use attractive industrial services. According to Nilsson (1996), a stimulating business is a business with business principles and community principles. Both principles are owned by cooperatives (Nilsson, 1996). Cooperatives can survive and do business in an economy full of uncertainty (Birchall \& Ketilson, 2009).

\section{Population and Samples}

In Ponorogo Regency, there are 972 active cooperatives (BPS, 2019). However, not all cooperatives have managers; only 119 cooperatives have managers. In this study, the unit of analysis was the cooperative manager. Following the formula from Rao (1996), its sample size was considered 54 respondents of managers.

\section{Operational Development and Variable Measurement}

This study involved three variables: management accounting system, decisionmaking style, and managerial performance. The operational and measurement definitions are labeled as follows:

Table 1. Operational Definitions and Measurement

\begin{tabular}{|c|c|c|c|}
\hline Construct & Operational Definitions & Instrument Sources & Scales \\
\hline $\begin{array}{l}\text { Management } \\
\text { Accounting } \\
\text { system }\end{array}$ & $\begin{array}{l}\text { Information that is used to make } \\
\text { managerial decisions (Vincent K } \\
\text { Chong, 1996) }\end{array}$ & $\begin{array}{l}\text { Robert H Chenhall and } \\
\text { Morris (1986) }\end{array}$ & Likert, 1-7 \\
\hline $\begin{array}{l}\text { Decision-Making } \\
\text { Style }\end{array}$ & $\begin{array}{l}\text { Individual's habit patterns in } \\
\text { making decisions (Scott \& Bruce, } \\
\text { 1995) }\end{array}$ & Scott and Bruce (1995) & Likert, 1-7 \\
\hline $\begin{array}{l}\text { Managerial } \\
\text { Performance }\end{array}$ & $\begin{array}{l}\text { Individual's quality and quantity of } \\
\text { work achieved by a person in } \\
\text { carrying out his duties by his/her } \\
\text { responsibilities }\end{array}$ & Mahoney et al. (1965) & Likert, 1-7 \\
\hline
\end{tabular}




\section{Data Analysis Technique}

\section{Testing Non-Response Bias and Descriptive Statistics}

In doing research, bias may exist due to the respondents' differences in responding and refusing to participate in filling out the questionnaire (Malhotra \& Birks, 2007). It is necessary to do a non-response bias test using the independent samples t-test. The data findings were analyzed using descriptive statistics. Moreover, this study utilized a Partial Least Square (PLS) approach to analyze field data findings. PLS is a variant-based structural equation analysis (SEM) that can simultaneously perform measurement testing and structural model testing (Abdillah \& Jogiyanto, 2015). PLS is also a variant-based SEM method designed to solve multiple regression when a specific problem occurs, including a small research sample (Jogiyanto, 2011).

\section{Measurement Model (Outer Model)}

The measurement model (outer model) is generated as the first stage in the PLS method. The outer model is to test validity and instrument reliability (Abdillah \& Jogiyanto, 2015). With the outer model, the loading factor value and AVE value will be known. The indicator is valid if it has a loading factor value $>0,70$, and an AVE value above $>0.50$, fulfilling the convergent validity requirements (Latan and Ghozali, 2012). Furthermore, the reliability test was carried out to measure the instrument's internal consistency, with two methods: Cronbach alpha and composite reliability (Jogiyanto, 2011). Cronbach alpha value and composite reliability produce suitable constructs if each has a value above $>0.70$ (Latan \& Ghozali, 2012).

\section{Structural Model (Inner Model)}

This structural model (inner model) is evaluated using $\mathrm{R}^{2}$ for the dependent construct, the path coefficient value, or $t$-value for each path to test the significance between constructs in the structural model (Abdillah \& Jogiyanto, 2015).

\section{RESULTS}

\section{Testing Non-Response Bias and Descriptive Statistics}

In this study, the primary data were obtained from respondents who returned 63 questionnaires via post, from 119 questionnaires sent to respondents. However, the data that could be analyzed was only 60 questionnaires. Moreover, the respondent participation was tested with non-response bias in table 2 and descriptive statistics in table 3 below.

Table 2. Testing Non-Response Bias

\begin{tabular}{lcccc}
\hline Constructs & $\begin{array}{c}\text { Mean } \\
\text { Awal (n=44) }\end{array}$ & $\begin{array}{c}\text { Mean } \\
\text { Akhir (n= 16) }\end{array}$ & t-stat & p-value \\
\hline Management acc. system & 79,9545 & 83,9375 & $-1,575$ & 0,121 \\
Decision Making Style & 130,1136 & 134,5000 & -0.495 & 0,622 \\
Managerial performance & 54,7273 & 54,6250 & 0,51 & 0,959 \\
\hline
\end{tabular}

Source: Processed Primary Data

Table 2 presented that the $p$-value of each construct had a value of $>0.05$. In other words, there was no significant difference between the two groups that gave the initial response and the final response. So, there was no response bias problem. 
Table 3. Descriptive Statistics

\begin{tabular}{lcccccc}
\hline \multicolumn{1}{c}{ Variables } & N & $\begin{array}{c}\text { Theory } \\
\text { Frames }\end{array}$ & Mean & $\begin{array}{c}\text { Actual } \\
\text { Rate }\end{array}$ & $\begin{array}{c}\text { Actual } \\
\text { Mean }\end{array}$ & $\begin{array}{c}\text { Dev. } \\
\text { Standard }\end{array}$ \\
\hline Management acc. system & 60 & $14-98$ & 56 & $62-96$ & 81,0167 & 8,76915 \\
Decision Making Style & 60 & $25-175$ & 100 & $70-167$ & 131,2833 & 30,14546 \\
Managerial performance & 60 & $9-63$ & 36 & $35-63$ & 54,7000 & 6,76557 \\
\hline
\end{tabular}

Source: Processed Primary Data

Table 3 indicated that all the constructs had an actual mean value higher than the theoretical mean, and the standard deviation value was smaller than the actual mean. So, the management accounting system constructs in cooperatives were widely used in decision making. Cooperative managers often carried out the construct of decision-making style in cooperatives. Meanwhile, the managerial performance construct showed that the manager's performance was good. The data for all constructs did not vary.

\section{PLS Analisis}

The outer model was conducted to measure the validity and reliability of research indicators. The second-order outer model resulted from the multidimensional management accounting system (MAS) and decision-making style. The path diagram and construct reliability and validity table after dropping the items were presented as follows:

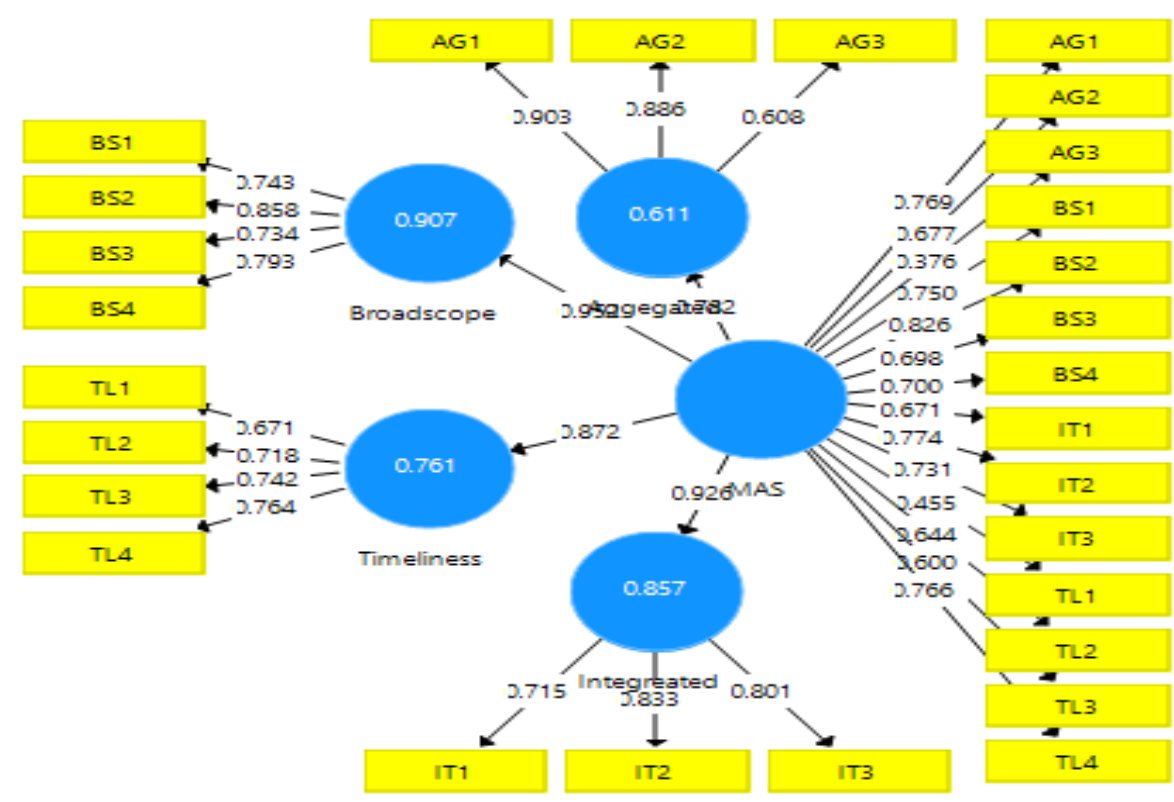

Figure 1. Path diagram of management accounting system 


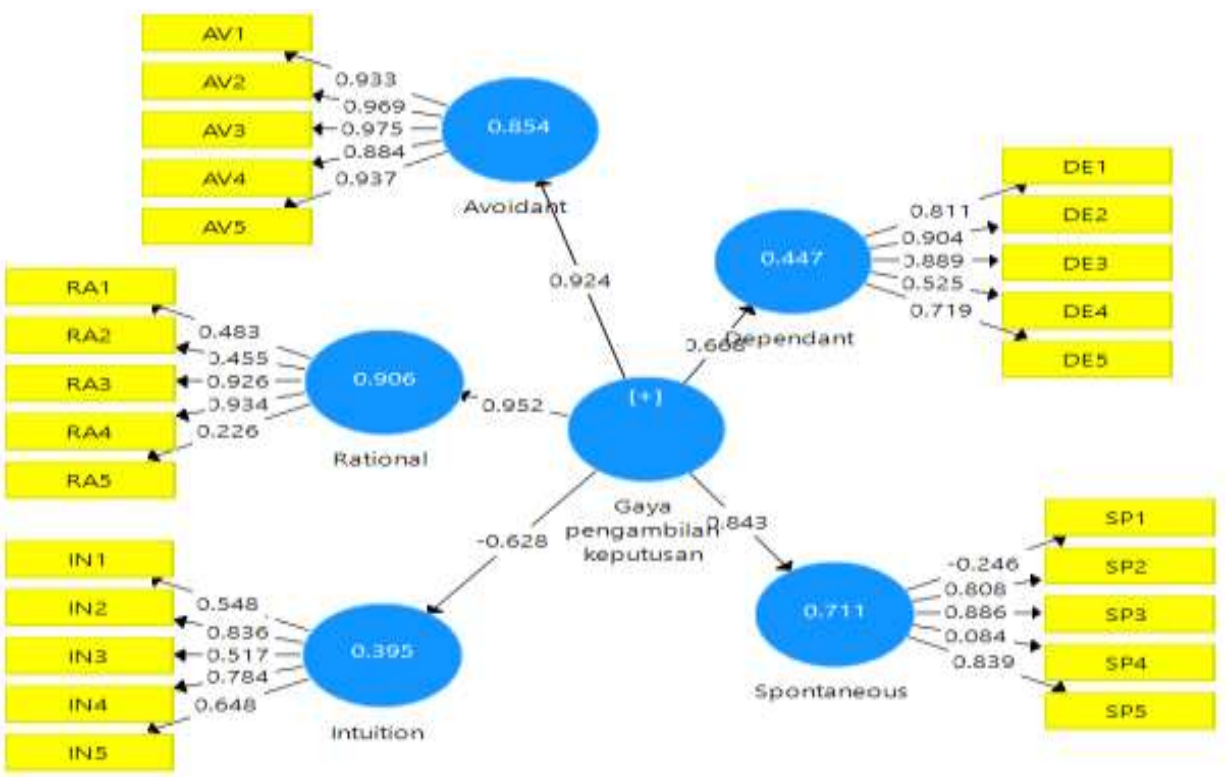

Figure 2. Path diagram of decision-making style

Table 4. Composite Reliability and AVE Construct of MAS and DMS

\begin{tabular}{cccccc}
\hline \multicolumn{2}{c}{ Management Accounting System (MAS) } & \multicolumn{3}{c}{ Decision Making Style (DMS) } \\
& $\begin{array}{c}\text { Composite } \\
\text { Reliability }\end{array}$ & AVE & & $\begin{array}{l}\text { Composite } \\
\text { Reliability }\end{array}$ & AVE \\
\hline Aggregated & 0,848 & 0,657 & Avoidant & 0,974 & 0,883 \\
Broadscope & 0,864 & 0,614 & Dependant & 0,884 & 0,612 \\
Integreated & 0,827 & 0,616 & D.M. Style & 0,859 & 0,380 \\
MAS & 0,923 & 0,469 & Intuition & 0,804 & 0,460 \\
timeliness & 0,815 & 0,525 & Rational & 0,767 & 0,444 \\
& & & Spontaneous & 0,668 & 0,442 \\
\end{tabular}

Source: Processed Primary Data

Table 4 demonstrated that the MAS construct's dimensions had a Composite Reliability value $>0.70$, and the AVE value was $<0.50$. In contrast, the decision-making style construct's dimensions involved a Composite Reliability value of $<0.70$ and an AVE value with a value $<0.50$. Thus, the indicators were less than the provisions. After removing indicators that did not comply with the provisions, the path diagram and composite reliability and AVE table are presented below: 


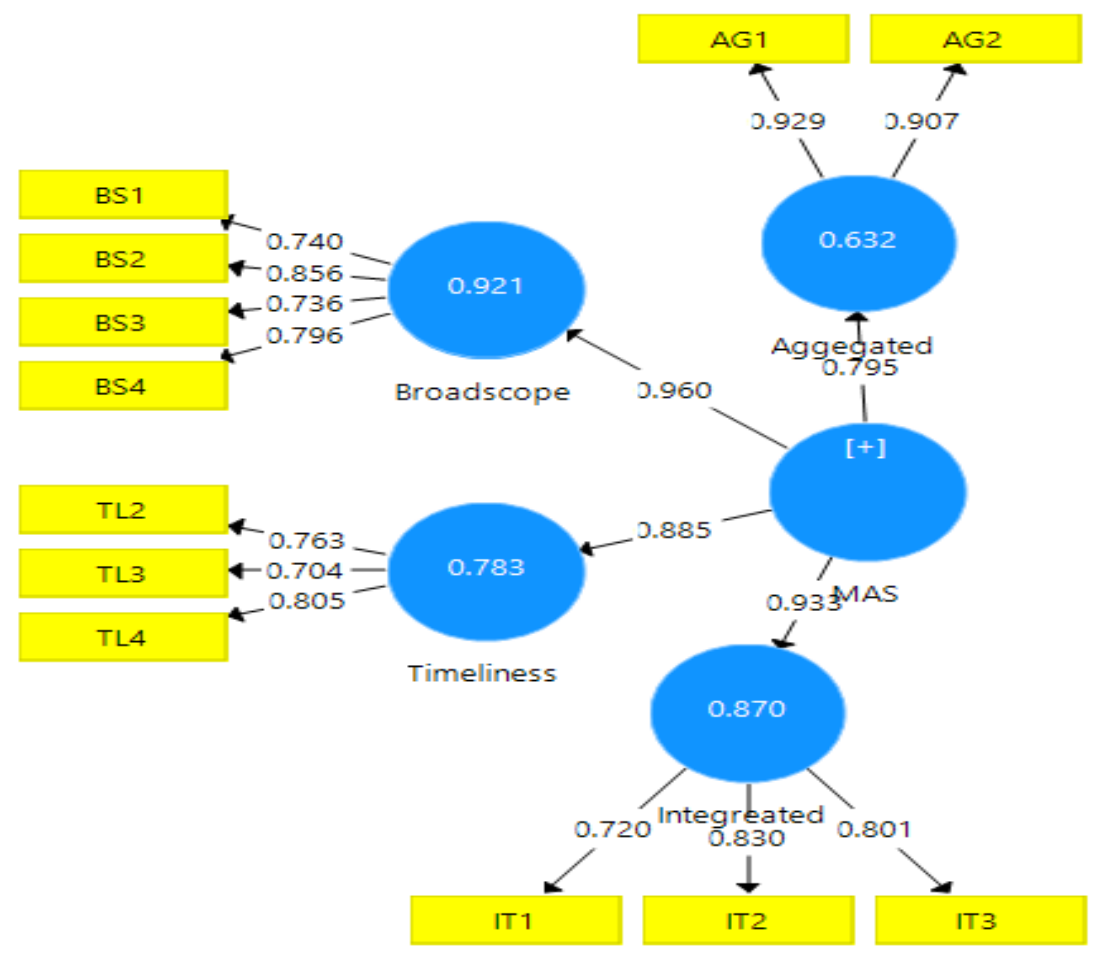

Figure 3. Path diagram of MAS after Issuing Invalid Indicator

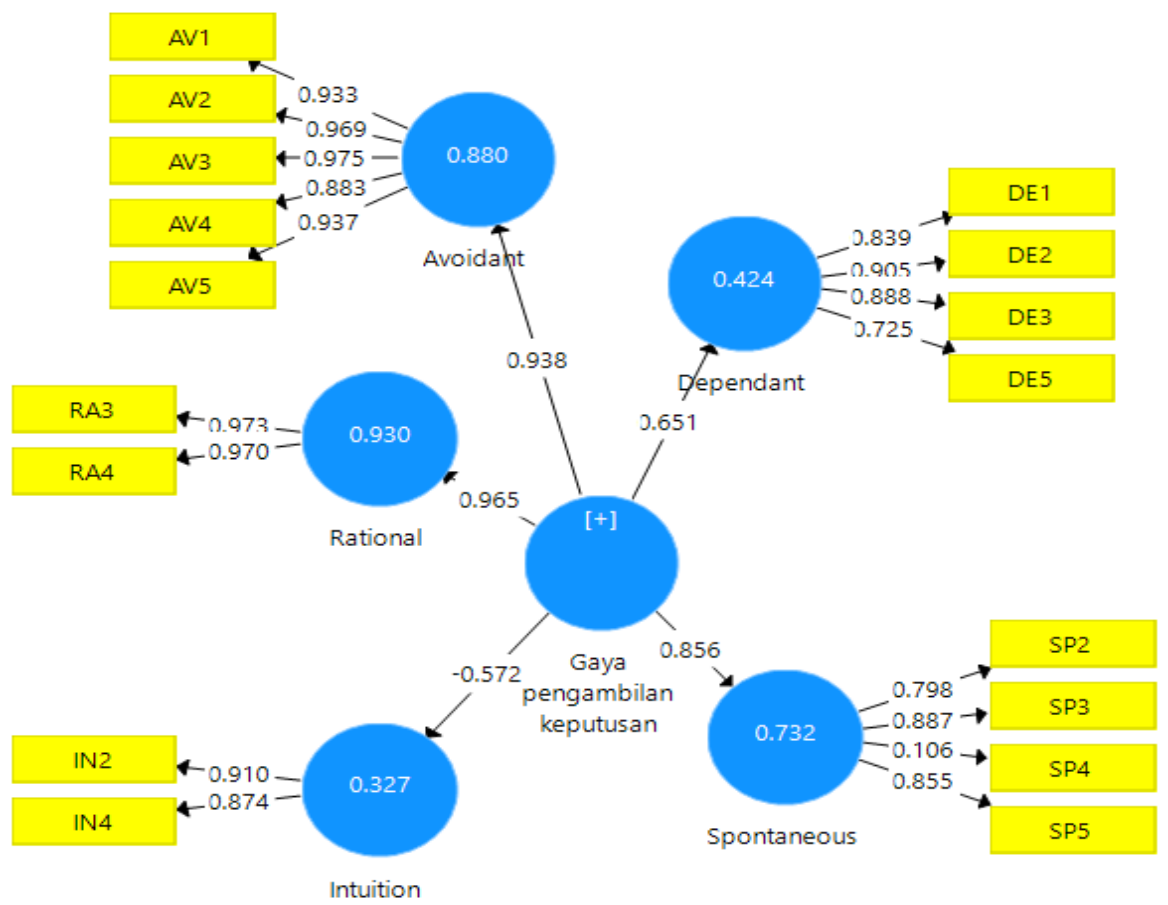

Figure 4. Path diagram of DMS after Issuing Invalid Indicator 
Table 5. Composite Reliability and AVE Construct of MAS and DMS after Issuing Invalid Indicator

\begin{tabular}{|c|c|c|c|c|c|}
\hline \multicolumn{3}{|c|}{ Management Accounting System (MAS) } & \multicolumn{3}{|c|}{ Decision-Making Style (DMS) } \\
\hline & $\begin{array}{l}\text { Composite } \\
\text { Reliability }\end{array}$ & AVE & & $\begin{array}{l}\text { Composite } \\
\text { Reliability }\end{array}$ & AVE \\
\hline Aggregated & 0,915 & 0,843 & Avoidant & 0,974 & 0,883 \\
\hline Broadscope & 0,864 & 0,614 & Dependant & 0,907 & 0,710 \\
\hline Integreated & 0,827 & 0,616 & $\begin{array}{l}\text { Decision Making } \\
\text { Style }\end{array}$ & 0,920 & 0,524 \\
\hline MAS & 0,929 & 0,523 & Intuition & 0,886 & 0,796 \\
\hline \multirow[t]{2}{*}{ timeliness } & 0,802 & 0,575 & Rational & 0,971 & 0,944 \\
\hline & & & Spontaneous & 0,792 & 0,541 \\
\hline
\end{tabular}

Source: Processed Primary Data

Table 5 indicated that the MAS and DMS constructs' dimensions had a composite reliability value of $>0.70$ and an AVE value of $>0.50$. Thus, the management accounting system (MAS) construct indicators and decision-making style (DMS) were valid and reliable. So it is necessary to continue at the next stage, namely the outer model of research with the SmartPLS program that can help to create the following figures and tables:

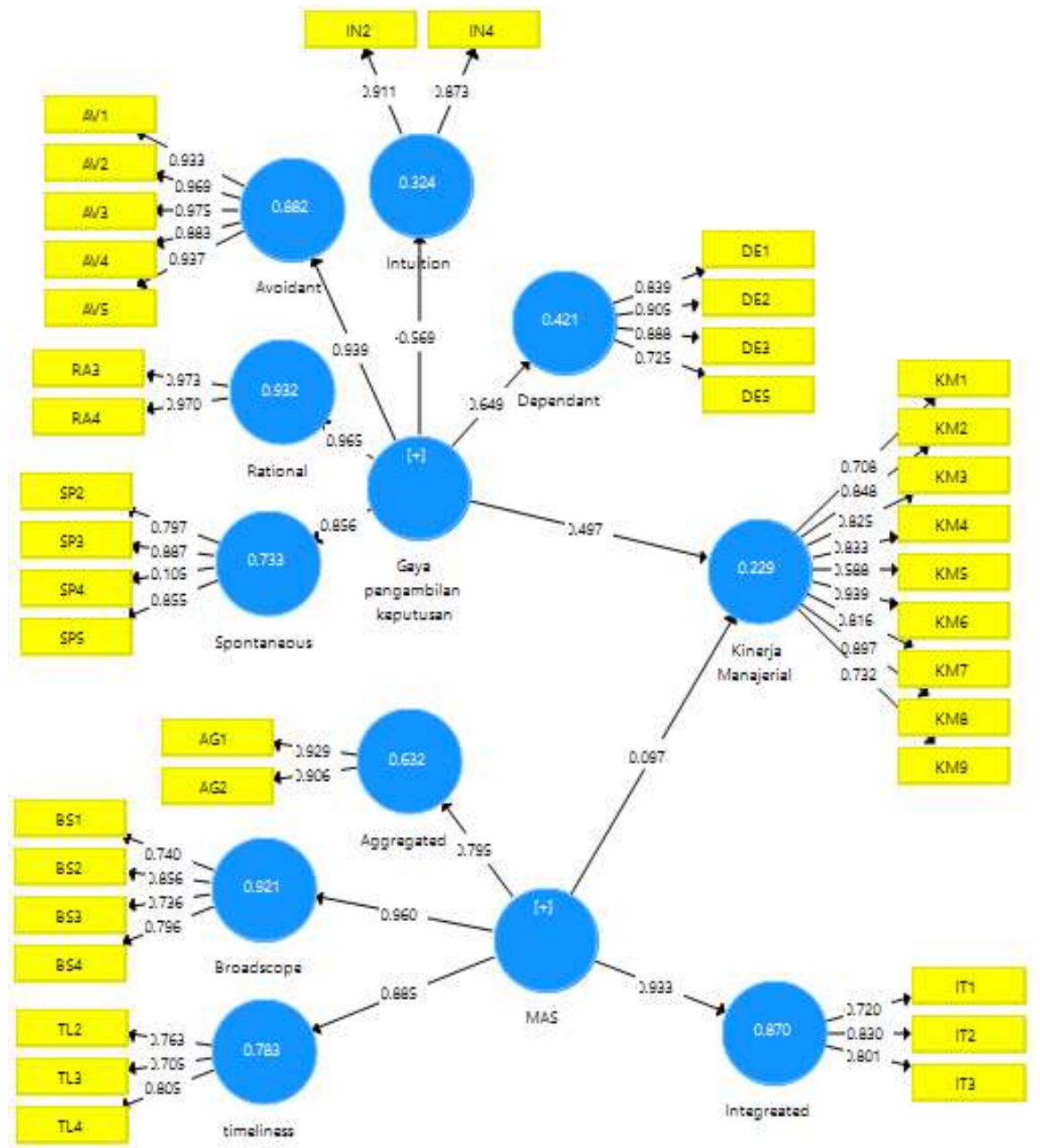

Figure 5. Outer Model of Research 
Table 6. Composite Reliability and AVE Construct on MAS and DMS

\begin{tabular}{lcclcc}
\hline & $\begin{array}{c}\text { Composite } \\
\text { Reliability }\end{array}$ & AVE & & $\begin{array}{c}\text { Composite } \\
\text { Reliability }\end{array}$ & AVE \\
\hline Aggregated & 0,915 & 0,843 & Intuition & 0,886 & 0,796 \\
Avoidant & 0,974 & 0,883 & $\begin{array}{l}\text { Managerial } \\
\text { Performance }\end{array}$ & 0,942 & 0,648 \\
Broadscope & 0,864 & 0,614 & MAS & 0,929 & 0,523 \\
Dependant & 0,907 & 0,710 & Rational & 0,971 & 0,944 \\
$\begin{array}{l}\text { Decision-Making } \\
\text { Style }\end{array}$ & 0,920 & 0,524 & Spontaneous & 0,792 & 0,541 \\
Integreated & 0,827 & 0,616 & timeliness & 0,802 & 0,575 \\
\hline
\end{tabular}

Source: Processed Primary Data

Table 6 showed the Management accounting system (MAS) construct, decisionmaking style, and the managerial performance had a composite reliability value of $>0.70$ and an AVE value of $>0.50$. The constructs were invalid and reliable. Thus, the analysis was continued to the structural model or inner model. Figure 6 and Table 7 showed the inner model below.

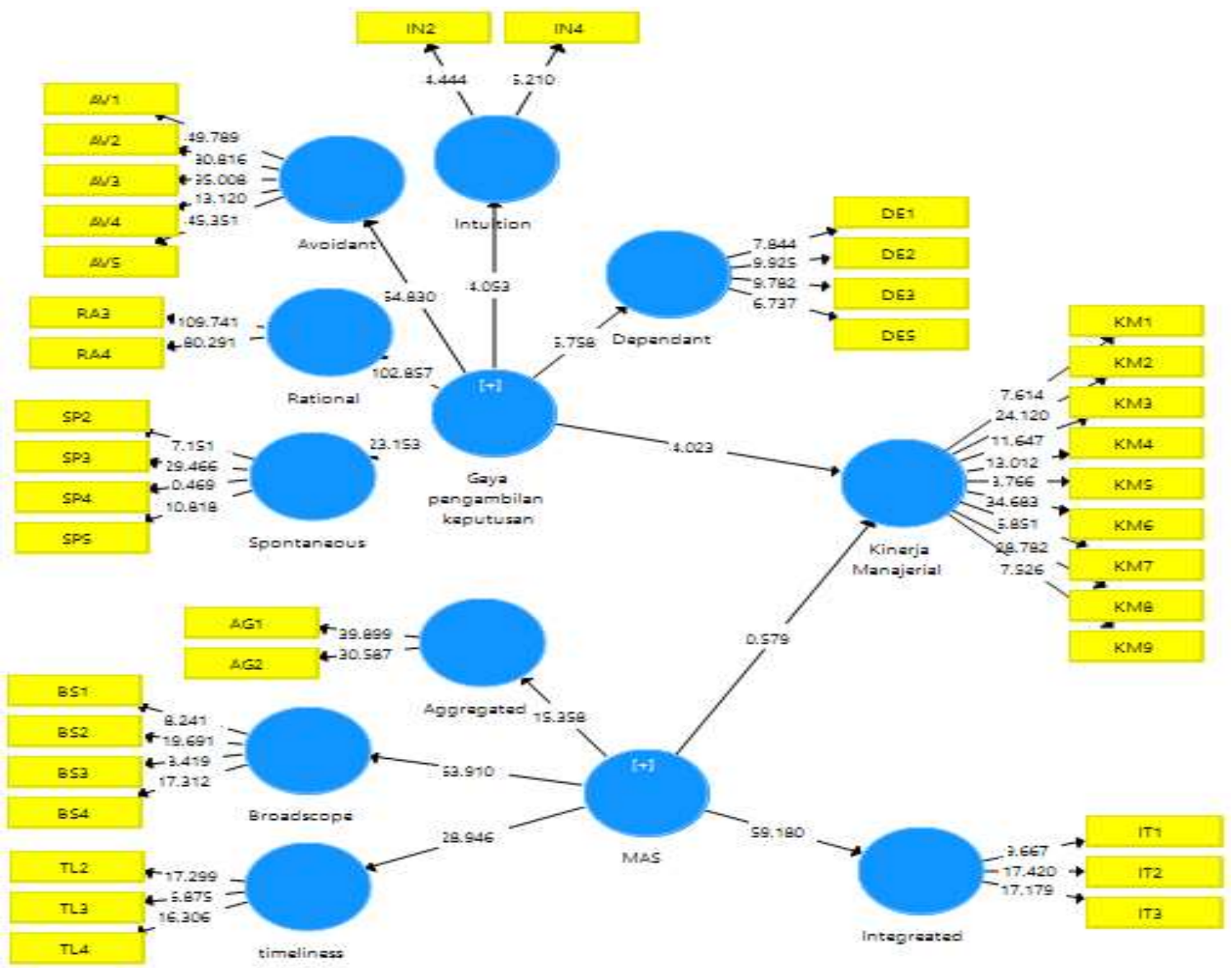

Figure 6. Inner Model 
Table 7. Path Coefficient of Management Accounting System (MAS), Decision-Making Style (DMS), and Managerial Performance

\begin{tabular}{lccccc}
\hline & $\begin{array}{c}\text { Original } \\
\text { sample }\end{array}$ & $\begin{array}{c}\text { Sample } \\
\text { mean }\end{array}$ & $\begin{array}{c}\text { Deviation } \\
\text { Standart }\end{array}$ & t-stat & p-value \\
\hline MAS $\rightarrow$ Managerial Performance & 0,097 & 0,122 & 0,168 & 0,579 & 0,563 \\
DMS $\rightarrow$ Managerial Performance & 0,497 & 0,530 & 0,124 & 4,023 & 0,000 \\
\hline
\end{tabular}

Source: Processed Primary Data

Table 7 presented the results of the hypothesis testing. MAS had no positive effect on managerial performance, as evidenced by the $\mathrm{p}$-value $>0.05$ and $\mathrm{t}$-stat $<1.96$. Meanwhile, the decision-making style affected managerial performance, evidenced by the $t$ statistical value $>1.96$ and the $p$-value $<0.05$.

\section{DISCUSSION}

The Effect of Management Accounting System (MAS) on Managerial Performance

Hypothesis one (H1) tested that the management accounting system (MAS) did not affect managerial performance. MAS's dimensions (e.g., broad-scope, timeliness, increased, and aggregated) did not affect managerial performance. The results of this study did not support the findings of Agbejule (2005), Agbejule (2011), S.O. Ajibolade et al. (2010), Bhimani (2012), and Solabomi O. Ajibolade (2013). This study concluded that MAS was related to performance, both managerial performance, and organizational performance.

\section{The Effect of Decision-Making Styles on Managerial Performance}

Hypothesis two (H2) tested that the decision-making style positively affected managerial performance. The increasing decision-making styles by cooperative managers would advance their performance. The finding supported the study of Rehman, Khalid, and Khan (2012) that employee decision-making styles affected organizational performance. Riaz, Riaz, and Batool (2014) concluded that avoidance style, as one of the dimensions of decision-making style, was predicted to influence organizational performance.

\section{CONCLUSION, IMPLICATIONS, AND LIMITATIONS}

This study concluded that the management accounting system (MAS) did not affect managerial performance, and the decision-making style had a positive effect on managerial performance. This study was implicated to cooperative managers. The managerial performance in the organization cannot be separated from the existing system in the institution. An essential system is information; in this case, it is MAS. Although the findings rejected the hypothesis, this study implies that MAS should be used as a basis by managers in their decision style to influence their performance. Otherwise, this study involved three limitations. The small samples of this study could not provide maximum results. The finding also did not differentiate between cooperative managers since the cooperatives had several types. Last, this study only used a management accounting system and decision-making styles as constructs that affected managerial performance. For further research, suggestions are delivered to increase the number of samples so that generalization can be appropriately done, to group the types of cooperatives so that a homogeneous manager can be selected as respondents, and to include the constructs of organizational culture and organizational commitment. 


\section{REFERENCES}

Abdillah, W., \& Jogiyanto. (2015). Partial Least Square (PLS) Alternatif Structural Equation Modeling (SEM) dalam Penelitian Bisnis Yogjakarta: Penerbit Andi.

Abernethy, M. A., \& Bouwens, J. (2005). Determinants of Accounting Innovation Implementation. Abacus, 41(3), 217-240.

Agbejule, A. (2005). The relationship between management accounting systems and perceived environmental uncertainty on managerial performance:a research note. Accounting and business Research, 35(4), 295-305.

Agbejule, A. (2011). Organizational culture and performance: the role of management accounting system. Journal of Applied Accounting Research, 12(1), 74-89.

Ajibolade, S. O. (2013). Management accounting systems design and company performance in Nigerian manufacturing companies: A contingency theory perspective. British Journal of Arts and Social Sciences, 14 Noll, 228-244.

Ajibolade, S. O., Arowomole, S. S. A., \& Ojikutu, R. K. (2010). Management Accounting Systems, Perceived Environmental Uncertainty And Companies' Performance In Nigeria. International Journal of Academic Research, 2(1), 195-201.

Ali, A. J. (1993). Decision-Making Style, Individualism, and Attitudes toward Risk of Arab Executives. International Studies of Management E Organization, 23(3), 53-73.

Alikhani, H., Ahmadi, N., \& Mehrava, M. (2013). Accounting information system versus management information system. European Online Journal of Natural and Social Sciences, 2(3(s)), 359-366.

Amazt, I. H., \& Idris, A. R. (2011). Lecturers' Satisfaction towards University Management \& Decision-making Styles in some Malaysian Public Universities Procedia Social and Behavioral Sciences, 15, 3957-3970

Arcelus, F., Melgarejo, Z., \& Simón, K. (2014). Managerial Performance Differences between Labor-Owned and Participatory Capitalist Firms. Journal of Small Business Management, 52(4), 808-828.

Atkinson, A. A., Kaplan, R. S., Matsumura, E. M., \& Young, S. M. (2010). Management Accounting Information for Decision-Making and Strategy Execution: Pearson Prentice Hall.

Baba, V. V., \& HakemZadeh, F. (2012). Toward a theory of evidence based decision making. Management Decision, 50(5), 832-867.

Baiocco, R., Laghi, F., \& D'Alessio, M. (2009). Decision-making style among adolescents: Relationship with sensation seeking and locus of control. Journal of Adolescence, 32, 963-976. doi: 10.1016/j.adolescence.2008.08.003

Bello, A., \& Zaria. (2005). The Role of Cooperative Societies in Economic Development. In M. Paper (Ed.).

Bhimani, A. (2012). Management accounting system implementation success: is reporting useful information sufficient? Int. J. Accounting, Auditing and Performance Evaluation, 8(2), 115-136. 
Birchall, J., \& Ketilson, L. H. (2009). Resilience of the Cooperative Business Model in Times of Crisis (1 ed.). Geneva: International Labour Organization.

Borman, W. C., \& Brush, D. H. (1993). More Progress Toward a Taxonomy of Managerial Performance Requirements. Human Performance, 6(1), 1-21.

Bouwens, J., \& Abernethy, M. A. (2000). The consequences of customization on management accounting system design. Accounting, Organizations and Society 25 (2000) 221 $\pm 241,25,221-241$.

BPS. (2019). Kabupaten Ponorogo Dalam Angka 2018. Ponorogo: BPS Kabupaten Ponorogo.

Brouseeau, K. R., Driver, M. J., Hourihan, G., \& Larsson, R. (2006). The seasoned executive's decision making style. Harvard Business Review, 111-121.

Chang, R.-D., Chang, Y.-W., \& Paper, D. (2003). The effect of task uncertainty, decentralization and AIS characteristics on the performance of AIS: an empirical case in Taiwan. Information \& Managemen, 40, 691-703.

Chenhall, R. H. (2003). Management control systems design within its organizational context: findings from contingency-based research and directions for the future. Accounting, Organizations and Society, 28, 127-168.

Chenhall, R. H., \& Morris, D. (1986). The Impact of Structure, Environment, and Interdependence on the Perceived Usefulness of Management Accounting System. The Accounting Review, LXI(1), 16-35.

Chia, Y. M. (1995). Decentralization, Management Accounting System (MAS) Information Characteristics And Their Interaction Effects On Managerial Performance: A Singapore Study Journol of Business Finoncc EAccounting, 22(6), 811-830.

Chong, V. K. (1996). Management Accounting System,Task Uncertainty and Managerial Performance: a Research Note Accounting, Organizations and Society, 21(5), 415-421.

Chong, V. K. (1998). Testing The Contingency 'Fit' Between Management Accounting Systems And Managerial Performance: A Research Note On The Moderating Role Of Tolerance For Ambiguity. British Accounting Review, 30, 331-342.

Chong, V. K., \& Eggleton, I. R. C. (2003). The Decision Facilitating Role Of Management Accounting Systems on Managerial Performance: The Influence of Locus of Control and Task Uncertainty. Advances in Accounting, 20, 165-119. doi: 10.1016/S08826110(03)20008-0

Chung, S.-H., Su, Y.-F., \& Yu-Ju, S. (2012). Broad scope management accounting system and managerial performance: The impact of role ambiguity and functional difference. African Journal of Business Management, 6(30), 8873-8878,. doi: 10.5897/ AJBM11.2181

Conteh, N. (2005). The Hypothesis Testing of Decision Making Styles in the Decision Making Process. Journal of Technology Research.

Cosgrave, J. (1996). Decision making in emergencies. Disaster Prevention and management, $5(4), 28-35$. 
Curseu, P. L., \& Schruijer, S. G. L. (2012). Decision Styles and Rationality: An Analysis of the Predictive Validity ofthe General Decision-Making Style Inventory. Educational and Psychological Measurement, 72(6), 1053-1062.

Dafna, K. (2008). Managerial performance and business success: Gender differences in Canadian and Israeli entrepreneurs. Journal of Enterprising Communities: People and Places in the GlobalEconomy, 2(4), 300-331.

Gul, F. A. (1991). The Effects of Management Accounting Systems and Environmental Uncertainty on Small Business Managers' Performance. Accounring and Business Research, 22(85), 57-61.

Gul, F. A., \& Chia, Y. M. (1994). The Effects Of Management Accounting Systems, Perceived Environmental Uncertalnti' And Decentrauzation On Managerlal Performance: A Test Of Three-Way Interaction. Accounting, Organizations and Society, 19(4/5), 413-426.

Hammad, S. A., Jusoh, R., \& Ghozali, I. (2013). Decentralization, perceived environmental uncertainty, managerial performance and management accounting system information in Egyptian. Internatiolnal Journal of Accounting $\mathcal{E}$ Information Management, 21(4), 314-330.

Hammad, S. A., Jusoh, R., \& Oon, E. Y. N. (2010). Management accounting system for hospitals: a research framework. Industrial Management $\mathcal{E}$ Data Systems, 110(5), 762784.

Harren, V. A. (1979). A model of Career decision making for college student. Journal of Vocational Behavior, 14, 119-133.

Indriani, M., \& Nadirsyah. (2015). Interaction Effect Of Budgetary Participation And Management Accounting System On Managerial Performance: Evidence From Indonesi. Global Journal Of Business Research, 9(1), 1-13.

Ismail, K., \& Isa, C. R. (2011). The Role of Management AccountingSystems In Advanced Manufacturing Environment Australian Journal of Basic and Applied Sciences, 5(9), 2196-2209.

Jerman, M., Kavčič, S., \& Korošec, B. (2012). The importance of the management accounting system in the decision making process: Empirical evidence from Slovenia. African Journal of Business Management, 6(24), 7252-7260.

Jogiyanto. (2011). Konsep dan Aplikasi Structural Equation Modeling Berbasis Varian dalam Penelitian Bisnis. Yogjakarta: UPP STIMN YKPN.

Kao, H., Kao, S. P.-H., Chen, S.-C., \& Chiu, K. K.-S. (2012). Decision Making Models And Knowledge Management Preferences: Taiwanese Expatriates in China. Australian Journal of Business and Management Research, 2(4), 1-11.

Lääts, K., \& Haldma, T. (2012). Changes In The Scope Of Management Accounting Systems In The Dynamic Economic Context. ECONOMICS AND MANAGEMENT, 17 (2), 441-447. doi: 10.5755/j01.em.17.2.2164

Latan, H., \& Ghozali, I. (2012). Partial Least Square Konsep, Teknik dan APlikasi: menggunakan program SmartPLS 2.0M3. Semarang: Badan Penerbit Universitas Diponegoro. 
Mahoney, T. A., Jerdee, T. H., \& Carroll, S. J. (1965). The Job(s) of Management. Industrial Relations, February, 97-110.

Malhotra, N. K., \& Birks, D. F. (2007). Marketing Research An Applied Approach (Third Edition ed.). England: Prentice Hall, Inc.

Mia, L., \& Chenhall, R. H. (1994). The Usefulness Of Management Accounting Systems, Functional Differentiation And Managerial Effectivenessl. Accounting, Organizations and Society, 19(1), 1-13.

Mihaela-Lavinia, C., \& Luciana, S. G. (2011). Models For Measuring The Economic And Managerial Performance. Journal Of Academic Research In Economics, 3(3), 225-259.

Moghadam, A. H., Tehrani, M., \& Amin, F. (2011). Study of the Relationship Between Emotional Intelligence (EI) and Management Decision Making Styles. World Applied Sciences Journal, 12(7), 1017-1102.

Moliner, G. H., \& Ruiz, M. E. G. (2004). Information Technologies: Challenge And Opportunity For Modern Management Accounting Systems. Paper presented at the International Conference on Artificial Intelligence and Emerging Technologies in Accounting, Finance and Taxation.

Nilsson, J. (1996). The Nature Of Cooperative Values And Principles Transaction cost theoretical explanations. Annals of Public and Cooperative Economics, 67(4), 633-653.

Phillips, S. D., Pazienza, N. J., \& Ferrin, H. H. (1984). Decision-making styles and problemsolving appraisal. Journal of Counseling Psychology, 31(4), 497-502.

Rao, P. (1996). Measuring Consumer Perceptions Through Factor Analysis. The Asian Manager, February-March, 28-32.

Rasid, S. Z. A., Isa, C. R., \& Ismail, W. K. W. (2014). Management accounting systems, enterprise risk management and organizational performance in financial institutions. Asian Review of Accounting, 22(2), 128-144.

Rausch, A. (2011). Reconstruction of decision-making behavior in shareholder and stakeholder theory: implications for management accounting systems. Rev Manag Sci, 5, 137-169.

Rehman, R. R., Khalid, A., \& Khan, M. (2012). Impact of Employee Decision Making Styles on Organizational Performance: In the Moderating Role of Emotional Intelligence. World Applied Sciences Journal, 17(10), 1308-1315.

Reyna, C., Ortiz, M. V., \& Revilla, Y. R. G. (2014). Exploratory structural equation modeling of the general decision-making style inventory. Revista de Psicología, 23(1), 33-39.

Riaz, M. N., Riaz, M. A., \& Batool, N. (2014). Managerial Decision Making Styles as Predictors of Personal and Organizational Outcomes of In-Service Employees Journal of Behavioural Sciences, 24(2).

Rinsum, M. V. (2006). Performance Measurement and Managerial Time Orientation. (Doctoral Philosophie), Erasmus University Rotterdam.

Robotka, F. (1947). A Theory of Cooperation Journal of Farm Economics, 29(1), 94-114. 
Rowe, A. J., \& Boulgarides, J. D. (1983). Decision Styles - A Perspective. Leadership E Organization Development Journal, 4(4), 3-9.

Royer, J. S. (1999). Cooperative Organizational Strategies: A Neo-Institutional Digest. Journal of Cooperatives, 44-67.

Scott, S. G., \& Bruce, R. A. (1995). Decision-Making Style: The Development and Assessment of a New Measure. Educational and Psychological Measurement, 55(5), 818-831.

Seaman, A. E., \& Williams, J. J. (2006). Management Accounting Systems Change And SubUnit Performance: The Moderating Effects Of Perceived Environmental Uncertainty. Journal of Applied Business Research, 22(1), 103-120.

Sisaye, S., \& Birnberg, J. G. (2014). Sociological Approaches to Organizational Learning: Applications to Process Innovations in Management Accounting Systems. Advances in Management Accounting, 23, 1-43.

Siyanbola, T. T. (2012). Accounting Information As An Aid To Management Decision Making. International Journal of Management and Social Sciences Research (IJMSSR), 1(3), 29-34.

Sohrabi, H., Talebnia, G., \& Nikjoo, M. (2014). The Effectiveness Of Management Accounting System On Management Performance. DAMA International, 3(3), 613 620.

Soobaroyen, T., \& Poorundersing, B. (2008). The effectiveness of management accounting systems: Evidence from functional managers in a developing country. Managerial Auditing Journal, 23(2), 187-219.

Spicer, D. P., \& Sadler-Smith, E. (2005). An examination of the general decision making style questionnaire in two UK samples. Journal of Managerial Psychology, 20(2), 137149.

Staw, B. M., \& Barsade, S. G. (1993). Affect and Managerial Performance: A Test of the Sadder-but-Wiser vs. Happier-and-Smarter Hypotheses. Administrative Science Quarterly, 38(2), 304-331.

Subandi, S. (2008). Strategi Koperasi Dalam Menghadapi Iklim Usaha Yang Kurang Kondusif. Infokop, 16, 102-125.

Tokic, M., Spanja, M., Tokic, I., \& Blazevic, I. (2011). Functional Structure Of Entrepreneurial Accounting Information Systems. International Journal of Engineering, IX(2), 165-168.

Tsui, J. S. L. (2001). The impact of culture on the relationship between budgetary participation, management accounting systems, and managerial performance: An analysis of Chinese and Western managers. The International Journal of Accounting, $36,125-146$.

Verma, N., Bhat, A. B., Rangnekar, S., \& Barua, M. K. (2015). Association between leadership style and decision making style in Indian organisations. Journal of Management Development, 34(3), 246-269. 
Verma, N., \& rangnekar, s. (2015). General decision making style: evidence from India. South Asian Journal of Global Business Research, 4(1), 1-40.

Watts, D., Yapa, P. W. S., \& Dellaportas, S. (2014). The Case of a Newly Implemented Modern Management Accounting System in a Multinational Manufacturing Company. Australasian Accounting, Business and Finance Journal, 8(2), 121-137.

Waweru, N. (2008). Predicting Change in Management Accounting Systems: The Effects of Competitive Strategy. GLOBAL JOURNAL OF BUSINESS RESEARCH, 2(1), 25-41.

Wessels, C. B., \& Vermaas, H. F. (1998). A management accounting system in sawmilling using activity based costing techniques. The Southern African Forestry, 183(1), 31-35.

Williams, J. J., \& Seaman, A. E. (2002). Management accounting systems change and departmental performance: the influence of managerial information and task uncertainty. Management Accounting Research, 13, 419-445. doi: 10.1006/mare.2002.0199

Young, B. S., Winfred Arthur, J., \& Finch, J. (2000). Predictor of managerial performance: More than Cognitive ability. Journal of business and Psychology, 15(1), 53-72.

Zenita, R., Sari, R. N., Anugerah, R., \& Said, J. (2015). The Effect of Information Literacy on Managerial Performance: The Mediating Role of Strategic Management Accounting and the Moderating Role of Self Efficacy. Procedia Economics and Finance, 31, 199 205

Zimmerman, J. L. (2001). Conjectures regarding empirical managerial accounting research. Journal of Accounting and Economics, 32(1), 411-427.

Zimmerman, J. L. (2009). Accounting for Decision Making and Control. New York: McGrawHill.

Zoni, L., Dossi, A., \& Morelli, M. (2012). Management accounting system (MAS) change: field evidence. Asia-Pacific Journal of Accounting \& Economics, 19(1), 119-138. 